\title{
Surfaces
}

\section{Introduction to and Discussion Summary of Chiyuki Kumakura's "History and Narrative in Japanese"}

\section{K. Ludwig Pfeiffer}

Volume 5, 1995

DEUXIÈME CONGRÈS INTERNATIONAL SUR LE DISCOURS HUMANISTE (1995)

SECOND INTERNATIONAL CONFERENCE ON HUMANISTIC

DISCOURSE (1995)

URI : https://id.erudit.org/iderudit/1064999ar

DOI : https://doi.org/10.7202/1064999ar

Aller au sommaire du numéro

\section{Éditeur(s)}

Les Presses de l’Université de Montréal

ISSN

1188-2492 (imprimé)

1200-5320 (numérique)

Découvrir la revue

Citer ce document

Pfeiffer, K. L. (1995). Introduction to and Discussion Summary of Chiyuki Kumakura's "History and Narrative in Japanese". Surfaces, 5.

https://doi.org/10.7202/1064999ar
Résumé de l'article

Dans le cadre du deuxième congrès international sur le discours humaniste, ce texte est une introduction à « Histoire et Narration en Japonais » de Chiyuki Kumakura, et rapporte les principaux pôles d'intérêt qui ont émergé au cours des discussions.
Copyright (c) K. Ludwig Pfeiffer, 1995

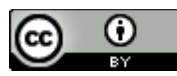

Ce document est protégé par la loi sur le droit d'auteur. L'utilisation des services d'Érudit (y compris la reproduction) est assujettie à sa politique d'utilisation que vous pouvez consulter en ligne.

https://apropos.erudit.org/fr/usagers/politique-dutilisation/ 


\title{
Introduction to and Discussion Summary of Chiyuki Kumakura's "History and Narrative in Japanese"
}

\author{
K. Ludwig Pfeiffer \\ Universität Gesamthochschule Siegen \\ Sprach - und Literaturwissenschaften
}

Surfaces Vol.V.206.1 (v.1.0A - 31/12/1995)

Copyright for texts published in SURFACES remains the property of authors. However, any further publication should be accompanied by an acknowledgement of SURFACES as the place of initial publication.

ISSN: $1188-2492$

\section{ABSTRACT}

In the context of the Second International Conference on Humanistic Discourse, this text introduces Chiyuki Kumakura's "History and Narrative in Japanese" and reports on the central concerns that emerged in its discussion.

\section{RÉSUMÉ}

Dans le cadre du deuxième congrès international sur le discours humaniste, ce texte est une introduction à «Histoire et Narration en Japonais» de Chiyuki Kumakura, et rapporte les principaux pôles d'intérêt qui ont émergé au cours des discussions.

1. Ever since Sapir/Whorf, the possibility of (radical) linguistic relativity and its possible consequences with respect to "worldpictures," types of discourse, and even sociocultural practice has loomed large. Relativity, that is, a tendency to conceptualize and categorize in very different ways, certainly seems to be built into the very structure of languages and in their vocabulary. On such an operational level, radical differences concerning the interpenetration of language, culture, and lifestyles have been frequently asserted with respect to Japanese and "others" (see, e.g., Bernice Z. 
Goldstein, Kyoko Tamura, Japan and America: A Comparative Study in Language and Culture, Rutland, Vt Tokyo: Charles E. Tuttle, 1975; Haruhiko Kindaichi, The Japanese Language, Rutland, Vt. Tokyo: Charles E. Tuttle, 1978). For others, while they do not claim any transcendental perspective of comparison relativizing relativity in its turn, discussion of differences always takes place, at least implicitly, on levels of dynamic relatability. Thus, when Mr. Kumakura points out the extreme speaker-orientation in Japanese, Westerners might argue that a growing awareness, from Kant down to radical constructivism (and even some present-day systems theory which holds the person to be a unique system of its own, taking everybody and everything else as environments), of (differently conceptualized) basic "subjective" factors has characterized Western thought as well.

2. While Mr. Kumakura alludes and refers to specifically Japanese examples of the radical relativity thesis (inscrutability, untranslatability), the main thrust of his argument goes into somewhat different directions. He is opposed to direct comparisons of linguistic structures; but he also maintains, more strikingly it seems to me with respect to consequences for cultural discourse, that "the Japanese in the past have never been able to define or clarify themselves and their culture adequately in European languages." But the crucial implication here, central to an enterprise concerned with the nature and function of humanistic discourses, is not primarily concerned with the translation of one cultural discourse into another. In Japanese, the speaker-oriented structure of the language rather turns into a problem for humanistic discourse itself. The discussion of the Japanese language does not promote the Sapir/Whorf hypothesis; it is geared towards the relations between humanistic discourse and the culture "at large." In Japan(ese), there is "no way of writing 'history' in the Western sense of the word." Generally, one may suspect, the "needs" of Japanese and Western cultures for and the possibility of humanistic discourse in the the sense of organized and institutionalized interpretational and theoretical activities are very different. In terms of quantity, the differences, throughout the centuries, seem striking indeed.

3. If, then (with apologies for such stark oppositions), Japanese is rather lococentric instead of logocentric (Augustin Berque), the interpersonal strain of a person's consciousness seems to provide a remedy for subjectivist limitations. Westerners may feel reassured and reminded, in Mr. Kumakura's paper, of G. H. Mead, who, as we know, has had quite an influence on Western humanistic discourses, including the foundational activities for the social sciences and humanities performed by Habermas and others. Unfortunately (for those Westerners), rather the opposite is the case. Owing perhaps also to the behavioral pressures in a densely populated and hierarchically well-ordered country, the mental and behavioral efforts of Japanese speakers to anticipate the surmised position of the other are intense indeed. The risks involved in that, however, may frequently induce a linguistic behavior which, for Westerners, seems to amount to a reluctance to commit oneself to any definite position - apart from speciously affirmative ones - at all. Anticipation, interpretation, then, may remain mental phenomena which need not be translated and institutionalized into (humanistic, e.g., psychologically oriented) discourse. It is comparable less to Western "phenomenological" accounts of consciousness than to Cicero's 
(or Pater's?) cultura animi. The comparison may be risky or even absurd; but the difference of relations between culture as represented for instance in texts and their institutionalized treatment - in itself a symptom of culture in the wider sense - might seem obvious enough. While types of discourse similar to psychoanalysis have, of course, been recently developed in Japan, too, it remains striking that Mr. Kumakura quotes narrative and drama in order to present patterns and compulsions of empathy. This is very far from types of texts like Dilthey's Das Erlebnis und die Dichtung to which Western humanistic discourses remain indebted even if they have drastically altered their theoretical make-up. Most conspicuously, the theoretical and interpretational management of time, its transformation into philosophies of history and hermeneutic schemes seems to separate the West from Japan.

4. Western cultural analysts - those at least captivated or attracted by what appears to be the opacity of Japanese culture - frequently assume, correctly to my mind, that the comparative lack of institutionalized cultural discourse correlates with and is compensated for by a more subtly elaborated culture of behavior and aesthetic sensibility. As Mr. Kumakura points out, the very existence of a large number of honorific terms is both an index (in Peirce's sense) of the speaker and of the objectifying social roles in which speakers are caught - or in which, at some point, they inevitably have to catch themselves, whatever they may think. Social (including age and gender) roles and aesthetic practice (from the tea ceremony, flower and plant arrangements, to "theater") might be called the "media" through which the elusiveness of interpersonality (in Mr. Kumakura's sense) and spirituality are patterned. This may also be one reason why the Japanese seem less troubled by what the West calls modern electronic media and their threatening impact on a more traditional culture of books and their interpretation.

As a polite Japanese, embodying what he presented, Mr. Kumakura did not ask direct questions about Western culture. Thinking, with the help of his paper, of Nietzsche and Foucault (that is to say of the Foucault of Histoire de la sexualité, where he seemed to become more concerned with cultural practices), one might venture into some perhaps unguarded questions: Have Western humanistic discourses perhaps been jumping in where the performative appeal of the arts (as parts of the arts of life) has become weaker or where a culture of behavioral performance has been on the wane? Could we say, for instance, that questions and theories concerning fiction and reality have become more urgent to the degree that the arts of interpersonality have been declining? In these respects, David Hume and the interpenetration of epistemology and sociability might still constitute an instructive example.

\section{Summary of Discussion}

The discussion was concerned mainly with the possibilities of distinction between western and Japanese notions of subjectivity (including the complementary notion of objectivity) and the avoidance of an essentialization of the "subjective factor." More precisely, the following questions were dealt with: What happens when Japanese sentences, admittedly subjective, are "subjected" to the "objectifying" pressures of texts 
like narratives or, for that matter, scientific procedures? What happens to translated (Western or other Eastern) texts and their cultural status? It seems doubtful whether, in principle, we can really distinguish between Western and Japanese critiques or conceptions of language (the struggle of language with language). On the other hand, in spite of the self-criticism implied in much of Western philosophy of language, its "objectifying" (perhaps pointing more to object-oriented than objective) tendencies seem to be more deeply entrenched.

In some respects, concepts like "fuzzy logic" might indicate a narrowing of the distance. One has to keep in mind, though, a distinction between language and conceptualization. The Japanese have been exposed to alien systems of conceptualization all through their history. While these may have been imposed, borrowed, and used, they have not led to creative or dynamic humanistic discourses and their modes of interpreting what one might call the primary culture or cultural performances. The grand theoretical gestures and claims as well as a continuous stream of interpretational activity are conspicuous more by their absence than by their presence.

Thus, the challenge of a practical paradox remains: We may not want anymore to subscribe to Sapir/Whorf theoretically. But yet its operational provocation does not vanish. The question of what the existence or absence of a (very) large body of humanistic discourses means with respect to the culture at large (are they part or parasites of it? Or taking these and more roles sometimes simultaneously?) has to be asked again. 